\title{
1. Introducing Highlands Sung Tales
}

\author{
Don Niles and Alan Rumsey
}

The genres of sung tales that are the subject of this volume are one of the most striking aspects of the cultural scene in the Papua New Guinea Highlands. Composed and performed by specialist bards, they are a highly valued art form. From a comparative viewpoint they are remarkable both for their scale and complexity, and for the range of variation that is found among regional genres and individual styles. Though their existence has previously been noted by researchers working in the Highlands, and some recordings made of them, most of these genres have not been studied in detail until quite recently, mainly because of the challenging range of disciplinary expertise that is required-in sociocultural anthropology, linguistics, ethnomusicology, and ethnohistory. To meet that challenge, with funding from the Australian Research Council an interdisciplinary research project on these genres was initiated at Australian National University in 2003. By 2006, when a week-long workshop on the tales was held in Goroka, Papua New Guinea, the project had grown to include fourteen researchers, from seven different universities and research institutes around the world (figure 1). These scholars come from all the disciplines referred to above, with field research experience in six different language regions within the overall project area.

This volume presents a set of interrelated studies by most of those researchers and by a Papua New Guinea Highlander who has assisted with the research based on his lifelong familiarity with one of the regional genres. As already suggested by the uptake of some of the related publications detailed in the penultimate section below, the studies presented here (all of them previously unpublished and written especially for this volume) are of ground-breaking significance not only for specialists in Melanesia or the Pacific, but also for readers with a more general interest in comparative poetics, mythology, musicology, or verbal art. Before introducing those studies and the genres themselves, we will provide a brief introduction to the overall region where they are found. 


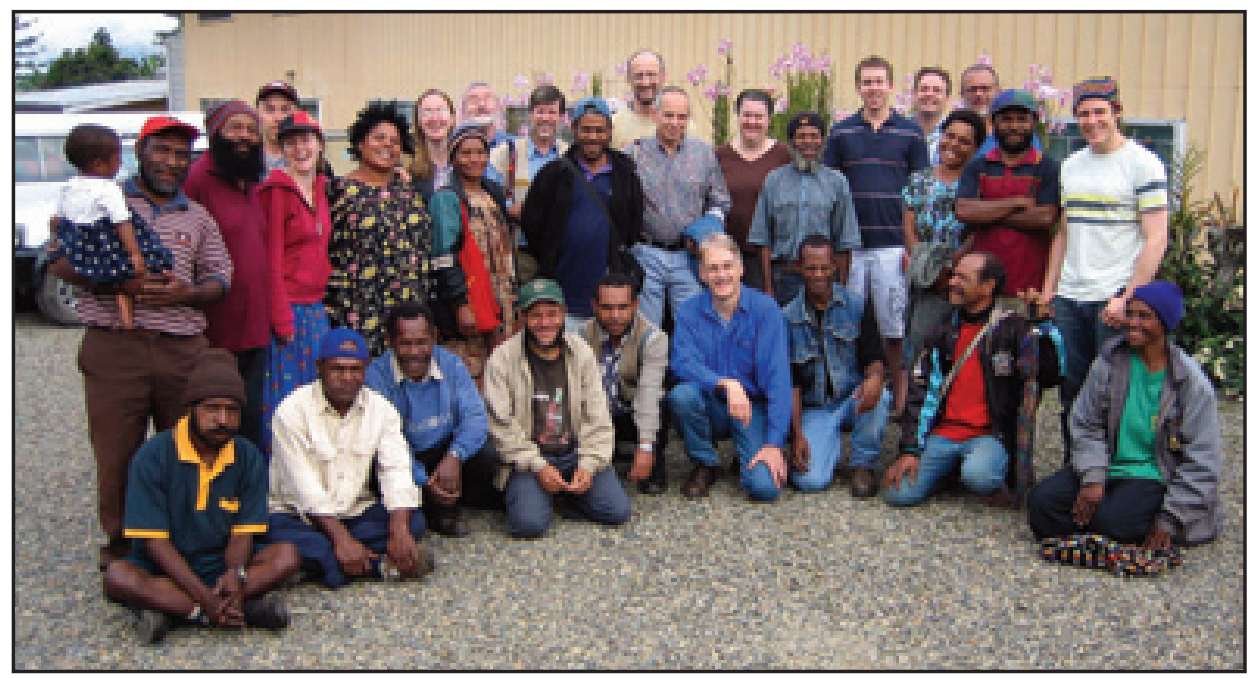

Figure 1. Participants at the conclusion of the 2006 Sung Tales Workshop, Kefamo, Eastern Highlands Province (near Goroka), 24 June 2006. Sitting/kneeling (left to right): Paulus Konts, Andrew Noma, Howard Halu, Alois Along, Joe Rex, Alan Rumsey, Richard Alo, Pita Tapuli, and Wapi Onga. Standing (left to right): Lewa Onga (baby), John Onga, Ru Kundil, Chris Haskett, Lila San Roque, Gomb Minimbi, Kirsty Gillespie, Snow Ru, Gabe C. J. Lomas, Philip Gibbs, Kenny Yuwi Kendoli, Hans Reithofer, Nick Modjeska, Nicole Haley, Josep Haip, Oliver Wilson, Ben Hall, Wan Minimbi, Don Niles, Peter Kerua, and Michael Sollis.

\section{The region}

The area within which we know that sung tales are composed and performed is shown in figure 2.

As can be seen from the inset map in the upper right corner of figure 2, this entire region lies within the interior of Papua New Guinea. Almost all of it is within the Highlands, where the settled areas lie at elevations of between 1,200 and 2,800 metres. The tropical highland climate, with its regular rainfall and year-round growing season, make much of this area well-suited to horticulture, which archaeology shows to have been going on there for at least five thousand years (Denham 2006). In the precolonial era, the central highlands-including most of the area shown as having sung tales in figure 2 and extending eastward for approximately $150 \mathrm{~km}$-was by far the most densely populated part of the island and remains so, apart from the coastal cities of Port Moresby and Lae (where many Highlanders now live also). Not unrelatedly, the central highlands is the part of Papua New Guinea where the languages have by far the largest numbers of speakers. For example, the Huli language has been estimated to have approximately 250,000 speakers (Lewis 2007), the Hagen-Nebilyer-Kaugel dialect continuum over 200,000 (Rumsey 2006a:52), and Enga about 300,000 
(Gibbs, this volume) - the most for any language/dialect group in Papua New Guinea. While none of these figures is very large by world standards, all are extraordinarily large in local terms, Papua New Guinea being a country with approximately 850 languages spoken by a total of about five million people.

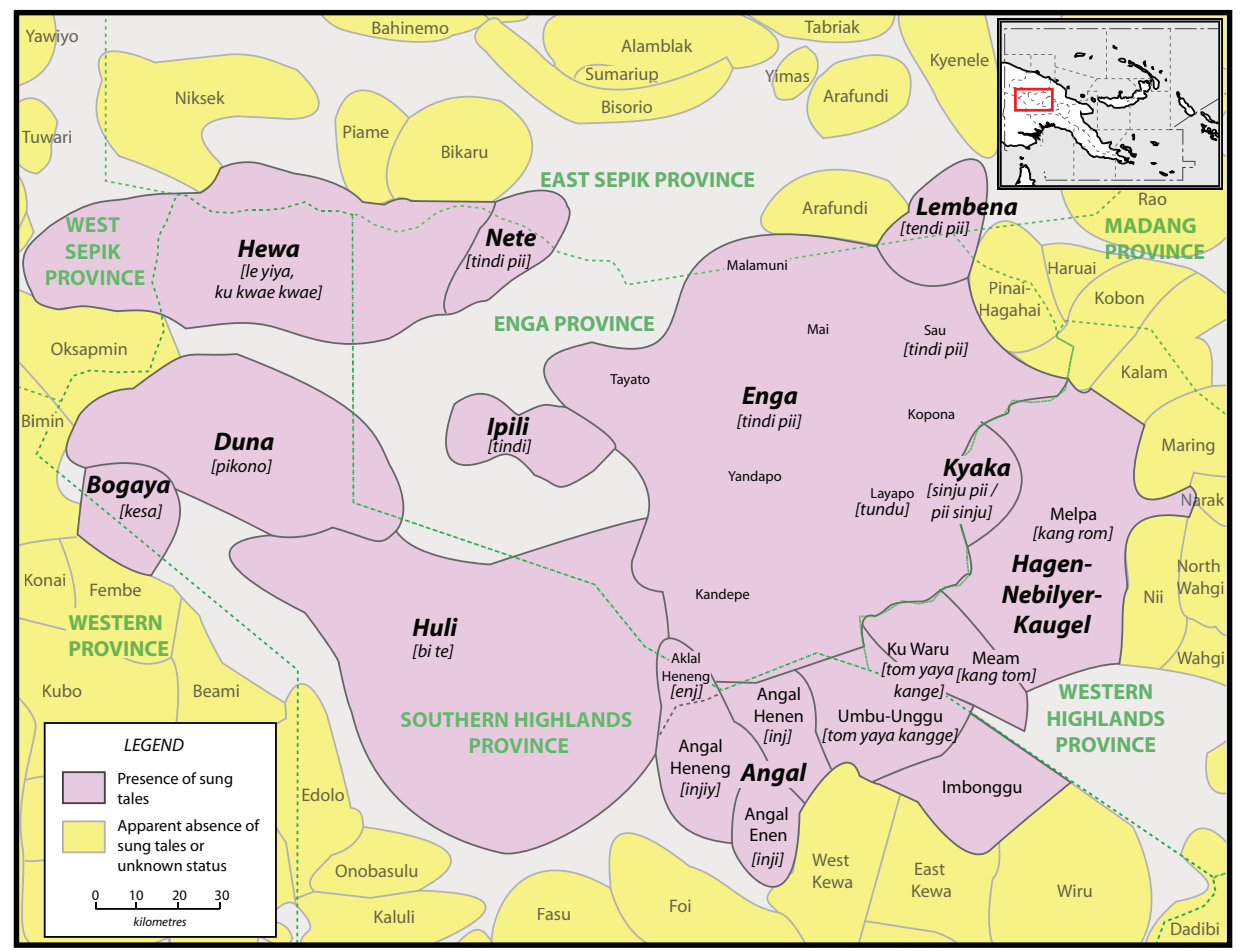

Figure 2. Sung tales in the Papua New Guinea Highlands. Language borders and names are based on maps found at the website of the Summer Institute of Linguistics, Papua New Guinea Language Resources (http://www.pnglanguages. org), with some modifications by Alan Rumsey and Hans Reithofer based on their own research.

While it has long been the most densely settled part of New Guinea, the central highlands was one of the last to come into contact with Europeans, which did not begin to happen until the 1930s. This means that, for much of the time during which many of the contributors to this volume have been doing research in region, there were still many people alive who could remember the period before the first Europeans arrived. This fact, along with the long isolation from the outside world, gives the genres treated here a special importance for comparative poetics, as they allow us to compare these genres with others found elsewhere in the world (for example, Scottish ballads as per Strathern and Stewart 1997, Homeric epics as per Rumsey 2001, or Chinese classical opera as per Rumsey 2007) with a high degree of confidence that any parallels that may be found are the result of independent developments rather than of direct historical influence. 
Approximately a million people live within the entire region shown on figure 2; the vast majority of them are rural-dwelling subsistence farmers. ${ }^{1}$ Sweet potato remains the staple crop across the region, supplemented by other long-established cultivars, including taro, bananas, sugar cane, and nut pandanus, and more recently introduced ones, such as cabbage, pineapple, avocado, and pawpaw. Across some of the region, especially in the eastern part, coffee is widely grown and is the main source of cash income. In the Ipili region, the Porgera gold mine, which has been in operation since 1989, has had a major effect on the local economy, as described by Borchard and Gibbs in chapter 8.

In the colonial era (which ended in 1975), public schools were established across most of the region, with schooling up to grade 6 being made available at local community schools and the higher grades at regional centres, where the best students could go and study as boarders. Partly because many families cannot afford the school fees that are now charged at all levels, and partly because the pay for teachers is not enough to attract them to the rural community schools, the overall standard of education and knowledge of English within the rural areas is seemingly lower in 2010 than it was in the 1980s. Across the region, local languages are still spoken as the first languages of nearly everyone, although nowadays nearly everyone can also speak Tok Pisin, the English-based creole that has become the country's main lingua franca. Politically, most people's strongest loyalties are to their local "lines" (tribe, clan, subclan, etc.), rather than to party, province, or nation, and the (usually short-lived) ruling alliances within the latter are built up out of the former.

Further ethnographic and historical background regarding particular areas within the overall sung-tales region is provided within the chapters pertaining to each. To conclude here regarding the region in general, we would like to point out that, taken together, the studies in this volume amply bear out a point made by Aletta Biersack in her introduction to a collection of studies concerning other aspects of the culture of a subset of the peoples treated here (Huli, Duna, and Ipili), namely that these peoples

have always been cosmopolitan, initially on a regional scale and today increasingly nationally and globally. A study of these Papuan borderlands exposes what earlier approaches concealed from view: the extensiveness of traditional intercultural exchanges, the importance of indigenous local/ global (that is, valley/regional) relations, and the centrality of questions of genesis and transformation to our empirical and theoretical work. (Biersack 1995:6; italics in original)

1 According to the 2000 census, only two of the handful of towns in the area had more than five thousand inhabitants: Mount Hagen (the capital of Western Highlands Province), with 33,623, and Mendi (capital of Southern Highlands Province), with 17,119. 
In line with this salutary observation, although the people whose sung-tale traditions are considered in this volume long remained relatively isolated from the world outside the Highlands, as the reader will see from the following sections and the rest of the volume, those traditions show a pattern of multiple, cross-cutting similarities and differences that can only have been produced by a long history of social interaction and intercultural exchange within the overall region.

\section{What are sung tales in the Papua New Guinea Highlands?}

Notwithstanding the differences among the sung-tale genres found across the region delimited in figure 2 , there are certain features that are common to all of them. Some of these are shared with other performance genres (e.g., ordinary storytelling, oratory, song), but others are distinctive to sung tales. Yet others are found only in sung tales, but not in all of the various regional genres of them. Here we will describe the main distinctive features of Highlands sung tales, noting the restrictions on their regional distribution where relevant.

Everywhere Highlands sung tales are vocal compositions performed solo and, to a large extent, composed during the performance. All across the region, the ability to do this is regarded as a specialized skill and is highly valued. ${ }^{2}$ The performer is usually male, although female performers are found in at least some areas. No instruments or dance accompanies the performance, but the performer may sometimes gesture or sway. The performer is usually seated, although at least in the case of male performers, they may lie down when performing in some areas, especially among the Enga and Karinj.

The main aim of the performance is usually said to be entertainment, although sometimes with an element of instructional value as well. The audience may be all male, all female, or a mixture, and may be seated or lying down, according to the region concerned. Another variable is the audience's verbal response. This ranges from silence in the Hagen area, to regularly required one syllable interjections, such as in Huli, to more lengthy questions or comments in Duna. Where interjections occur, they do not interrupt the flow of the story, but may be used by the performer to shape expressions or events in a certain way. In many cases, small payment is made to the performer after the performance.

2 As exemplified for the Hagen area by the discussion of Paul Pepa and Paulus Konts in chapters 11 and 12 (cf. Rumsey 2006b), and as corroborated for other areas by discussion with sung-tale performers at the 2006 Goroka workshop, this skill seems generally to be developed by imitation rather than by explicit instruction or institutionalized apprenticeship. 
In all performances, the language used is somewhat different from normal speech, involving special vocabularies, expressions, word substitutions, and vocables or extended vowels at the end of a line or section. The frequency of vocables and the different registers of esoteric speech vary across regions.

The story is presented as a narrative. It is not secret and is not considered "true," but the characters are placed in a real landscape of known places within the area where it is performed (although sometimes distant places, known only by repute, are also mentioned). The story often involves recognizably good versus bad characters, a journey to a distant land, and a romance. In some traditions, new people and places are inserted into more traditional stories. Sometimes encounters with spirits feature in the plot. Some groups find such stories inspirational before fighting or use stories involving a number of stock characters or featuring battles.

The melodic presentation of sung tales varies considerably throughout the region with respect to the melody itself, its range, and its contour. Usually the text is set syllabically (one pitch per syllable), but exceptions are frequent in some areas. The melodies of some sung tales bear an obvious relation to other genres more readily recognized as song. For most of the areas, however, our knowledge of musical expression is not advanced enough to allow any conclusions to be drawn on this question.

Other variables in presentation concern the presence or absence of a recurrent beat or pulse, or of a repeating metre. Tempo is also highly variable across the region, as is the length of sung phrases, of silences/breaths, and of the entire performance itself. Pugh-Kitingan (1981:332) reports that Huli bi té can "last for a few seconds, several minutes or hours." Enga tindi pii can be over an hour (Wiessner and Tumu 1998:27), while Duna pikono can last many hours. Performances in other areas lie between these extremes.

Finally, although in English we have given a special name to the genre under consideration here, in most areas the same word or expression is commonly used for sung tales and stories presented in normal speech, with only an acknowledgement that the former are considered especially aesthetically appealing. In the Hagen area, sung tales are specially named, but as a subtype of a narrative genre that also includes spoken stories. While in the Aluni area of the Duna-speaking region, the term pikono appears to only be used for sung tales (Strathern and Stewart, pers. comm., July 2010), in other parts of the same language area, pikono can apply to spoken stories as well (Gillespie and San Roque, this volume, chapter 3).

In the next three sections, more detailed consideration will be given to three particularly important aspects of the performance of sung tales: plots and characters, poetry, and music. 


\section{Sung-tale plots and characters}

Throughout the Highlands of Papua New Guinea, there is often a fundamental division made between two types of narratives: one which relates events known or witnessed by the teller, the other which tends to contain more fantastic elements. So, for example, there are the contrasts between Enga atome pii and tindi pii, Kyaka arome pii and sinju pii, Melpa teman and kang, Ku Waru temani and kange, Karinj arman and enj, Erave ramani or ora piei and lidi, respectively. For such genres, a fact versus fiction dichotomy is too simplistic (see, for example, Merlan 1995; Rumsey 2001:200; Reithofer 2006:17-19), but wherever sung tales are found in the Highlands, they belong to the latter category. In most cases the stories rendered in sung form are ones that are sometimes also told in spoken form. But to a greater or lesser extent across the region, the plots and characters of the stories that are performed in sung versions tend to be drawn from particular subsets of the wider range that are told in ordinary spoken form. In what follows we will present a brief summary of some of the main tendencies in that respect, beginning with the Duna region at the western end of the project area and working our way east to the Hagen region.

The main plots and characters of Duna sung pikono are very informatively discussed and exemplified in chapter 2 by Kenny Yuwi Kendoli, a Duna (Yuna) ${ }^{3}$ man with long insider experience of pikono. Consistent with earlier accounts of the genre by Haley (2002) and Stewart and Strathern (2002a, 2005), Kendoli highlights as leading dramatis personae the 'cannibal giants' (auwape), the 'pikono boys', and 'beautiful women'. The cannibal giants were the first humanlike beings to inhabit the earth, but were not fully human. The story-world of pikono is located in the ancestral past at a time when the cannibal giants and full-fledged humans of the present form were both alive, albeit in different zones. Mediating in some ways between these two kinds of beings is the figure of the payame ima, the 'Female Spirit' who typically takes the form of a beautiful young woman and acts as a guardian to the pikono boy, helping him defeat the cannibal ogre and grow into mature manhood. Most pikono tales centrally involve a journey undertaken by one or more of the pikono boys, who encounter obstacles and struggle to overcome them. Often, as pointed out by Kendoli, there are fights between the pikono boys themselves, which, as discussed and exemplified by Stewart and Strathern (2002a, 2005), may pit a pair of brothers against each other, one of them being a good one, who is nurtured by the Female Spirit, and the other a bad one, who teams up with the cannibal giants.

3 The term "Duna" (derived from a Huli designation) is conventionally accepted as standard reference in English and Tok Pisin (see also Haley 2002:14). The indigenous self-designating term which is used by Kendoli in his chapter is Yuna. This word may itself be interpreted as a gradable rather than absolute term (Strathern and Stewart 2004:11). 
As Kendoli observes, in past times pikono had a close connection with the Duna bachelor cult, a ritual complex in which boys were held in seclusion and initiated into the mysteries of growth and attraction under the tutelage of ritual specialists who were said to be the 'husbands' of the Female Spirit (cf. Stewart and Strathern 2000b:15-16; 2002b:102-40). Although Kendoli is too young to have gone through the bachelor cult himself, according to what older men have told him (as reported in his chapter), it seems that the connection with pikono consisted both in the fact that the cult was one of the main settings in which they were performed, and in the fact that the main characters in them, the "pikono boys', were cast as initiands in the cult, who were aided by the Female Spirit in the course of their travels, just as were the actual initiands by her 'husbands' in the cult houses (cf. Stewart and Strathern 1999).

Among the Huli immediately to the southeast of the Duna, sung bì té tales have much in common with Duna pikono. The Huli too had a 'bachelor cult' (hâroli), with which the central male characters in bi té are often associated-although as pointed out by Lomas in chapter 5, "their status as häroli is usually implied rather than stated." Lomas further explains that bì té bards

have a wealth of traditional tales to draw upon, with generally two or more human characters in each tale. Sometimes a tale may carry a romantic interest, and there is nearly always some sort of supernatural element involved, such as a non-human spirit or a paranormal event ... Frequently, one of the human characters goes off on a journey, often into a high mountainous rain-forest where dāma "spirits" dwell. These spirits may be ogre-type beings that eat human flesh, cannibals that devour each other, or slippery tricksters likened to the iba tīri 'eels' that inhabit the waterways. (Lomas, this volume; cf. Pugh-Kitingan, this volume)

Further to east among the Angal Heneng, there are many similarities between the typical plots of enj sung tales and the Huli and Duna ones summarized above. The cannibal ogre figure (locally known as Wan Heyo) appears in many tales as the central antagonist of the young male, and a Female Spirit figure as his guardian. Among the Angal Heneng as among the Enga to the north of them, the Female Spirit is identified with a "sky world" from which she comes down to help the boy, usually taking him back there with him (Reithofer, this volume). Other enj stories do not involve a sky woman or a cannibal at all, and are thought of as being more for entertainment than moral edification (ibid.).

The theme of the "sky world" and its interaction with the terrestrial one is perhaps most central among the Enga and Ipili, as described in the chapters by Gibbs and by Borchard and Gibbs. In these areas too, the stories often include cannibalistic ogres — both male and female - as central figures, and links to the male initiation rites are common. Gibbs (this volume) says of Enga tindi pi that the "underlying themes include the seeking of adulthood, a quest for beauty, and the search for a better world." 
Further to the southeast and east, the sky world figures far less centrally, if at all, in sung tales in the Ku Waru and Melpa regions, ${ }^{4}$ where they are known as tom yaya kange and kang rom, respectively. Nor was there any association with initiation rituals, which, as far as we know, were not practised within this region at any time within the reconstructable past. The kind of relationship between young male and female figures that appears most centrally in this area is not one of tutelage, but one of courtship. As discussed in the chapter by Rumsey, ten of the twenty-five sung tales from the $\mathrm{Ku}$ Waru region he has recorded display variants of a standard plot in which a young man sets out from his home to court a young woman he has heard about in a far-away place, wins her hand, but then encounters various obstacles in his attempt to bring her back to his home and marry her. Among the neighbouring Melpa - who are at the far eastern end of the sung tales region - all of the eight or nine kang rom that have been recorded display variants of this plot. While this gives them a distinctive cast quite different from the plots from further to the west that we have reviewed above, there is an intermediate link in that, as pointed out by Strathern and Stewart (2005:15-16), the plot and figure of the courted maiden in one of the sung tales recorded by Rumsey in the $\mathrm{Ku}$ Waru region (presented and discussed in chapter 11) share key elements with tales of the bachelor boy and the Female Spirit from the other regions as discussed above (although in this tale the relevant female protagonist is not explicitly identified as a sky being).

In short, as anticipated by the discussion above, across the entire region of the Highlands where sung tales are found, the range of traditional plots and characters in them is a continuous one, with differences of emphasis, and with some elements limited to particular subregions, but with some elements common to most of them. Among the latter are the centrality of a journey that is undertaken by the main character or characters - often a young man and woman who have come together of their own accord.

Especially in the eastern reaches of the sung-tales region, among the Melpa and $\mathrm{Ku}$ Waru areas, new variants of these longstanding plots and characters have been developed to deal with current themes. In the Ku Waru area discussed by Rumsey in chapter 11, one performer, Paulus Konts, has cast himself as the suitor in a tale with a standard plot of courtship that is, however, located in the here and now, with the journey taking place along the Highlands Highway and through the town of Mount Hagen. In another tom yaya kange, also featuring himself in the leading role, Konts sang of an imaginary journey to the coast to buy betelnuts and bring them back across the Highlands to the Porgera gold mine

4 None of the thirty or so sung tales recorded from this region involves sky people as dramatis personae. As discussed in chapter 11, there is some evidence that one such story was formerly performed as a sung tale, but no longer is. 
in Enga Province to sell them at a great profit. ${ }^{5}$ At the 2006 Goroka workshop, another Ku Waru bard, Peter Kerua, performed a tom yaya kange about a tribal war that his group was involved in at that time. ${ }^{6}$

In the neighbouring Melpa region, the last two kang rom by the renowned performer Paul Pepa were composed on commission from candidates in nationallevel elections in aid of their campaigns. At least one of them featured a journey of courtship (in a wide-bodied Toyota Land Cruiser, rather than on foot), used in an allegorical way to laud the candidate's ability to build coalitions and court the vote. In all of these cases, we see pre-existing plots and character types in the sung-tale genre being adopted, both to bring the genre into the contemporary world and to invite its audience to imagine that world in terms of the earlier one which is otherwise portrayed within such tales (as discussed in Rumsey 2006a).

In other cases the distinctive poetic and musical features of sung-tale genres have been used to present narratives that do not necessarily have any close connection with the longstanding plots and characters used for these genres. For example, sung-tale musical and poetic conventions have in several cases been drawn upon for presenting the Christian gospel ${ }^{7}$ and for settings of Christian liturgy. ${ }^{8}$

Finally, another interesting case of the adaptation of features of the sung-tale genre has been reported by Goldman (1998) from his work on Huli children's "fantasy play." He found that during the course of their play routines, in a practice resembling some uses of "sportscaster talk" among Western children, Huli children would self-narrate the imaginary scenes they were acting out, playing the parts of, for example, Australian patrol officers, Papua New Guinea riot police, and urban criminals. Remarkably, when doing so even children as young as four to five years old would use the intonational style of bi té sung tales. While the characters and scenarios they were enacting bore no direct relation to those of bi té, by drawing on its performance conventions, at a more general level they placed the story-world of bi té in a two-way analogical relation with the contemporary one (cf. Rumsey 2005:71-74), attesting to the continuing salience of bi té as what Goldman (1998:145) calls "a way of making narrative sense of the world."

5 For plot summaries and discussion of these two stories by Konts, see Rumsey (2005:60-66).

6 For the first eight lines of this performance, see chapter 12.

7 For a Ku Waru case in which a Lutheran man from the Upper Kaugel Valley composed and performed a tom yaya kange about the life of Jesus, see Rumsey (2001:201).

8 Examples from his missionary work among the Enga were discussed by Philip Gibbs at the 2004 and 2006 Goroka workshops, as were examples from Huli by Gabe Lomas. As discussed and referenced in the section on published sources below, Lomas was the co-compiler of a Huli-language setting of the Roman Catholic mass that drew, inter alia, on the genre conventions of bi té sung tales. 


\section{Special forms of language used in sung tales}

Sung tales often employ special vocabulary, different from that used in normal speech. In some cases this vocabulary is considered to be "archaic" or to have been borrowed from other languages. For example, in their transcription of part of a Duna pikono, Stewart and Strathern (2005:89-91) put asterisks next to words identified by Duna speakers as 'archaic/poetic ('special,' not the ordinary usage in Duna day-to-day speech)" (ibid.:89). In discussing this vocabulary, they note that the usual word for 'cassowary' is ukura, but in pikono the term yari is used, a word found in neighbouring languages (ibid.:93). In chapter 2 of this volume, Kenny Kendoli comments extensively on the use of these special alternative vocabulary items or 'praise names', and how essential they are to good pikono performance. For many everyday Duna words there is more than one alternative kẽiyaka 'praise name' replacement form. In chapter 3, Gillespie and San Roque discuss the way in which alternative kẽiyaka expressions are used at particular positions with successive lines of pikono, especially in reference to places or features of the landscape (see also Stewart and Strathern 2000a; Strathern and Stewart, chapter 13, this volume; Gillespie 2010, chapter 2). Haley (2002) shows that some of the alternative kẽiyaka forms are associated with particular zones or regions within Duna country, so that, for example, a tree species for which there is a single word in everyday Duna will be called by different praise names depending on whether the characters in the story are encountering it in a montane forest or in a settled area at lower altitude.

Various kinds of substitute vocabulary are also common in Enga songs (Brennan 1970:28-30, 46-47) and other vocal traditions throughout the area.

With respect to the Melpa area, Strathern and Stewart (2005b:217) refer to the difficulties in transcribing and translating Melpa kang rom texts because of the "rich and archaic vocabulary that permeates the text," but also because of the possible variable interpretations resulting from slightly different hearings of the text, for example, whether the performer sings pili or pilin, köni or könin. Considering the speed of Melpa kang rom performances, such possibilities challenge all listeners.

Within the Ku Waru region to the southwest, Rumsey finds that words used in tom yaya sung tales are generally everyday ones, but that they are sometimes used in ways that are unique to tom yaya kange. This occurs especially with a set of oftrepeated formulaic lines that performers use to frame their narratives in relation to the performance event: "And who's ever heard such a thing? / And who's ever seen such a thing," "In my mind's eye the story unfolds," etc. There is also a standard expression that is often used to open a tom yaya kange performanceama na na na (literally "Oh mother, I, I, I") — and other expressions that are used to close them: konta mong rltup rltap "Now the ball stops rolling," dalu mong 
kerikar "The banana-leaf curtains draw shut," etc. Certain other words are used only in tom yaya kange and are said to be part of what makes it "sound like tom yaya kange," as exemplified in chapter 11.

Another aspect of the poetic form of sung tales is the ordered interplay of repetition and variation, or what students of comparative poetics call "parallelism." A feature common to all the sung-tales genres treated in this volume is that the main level at which parallelism abounds is the line. From line to line, each instance of partial repetition establishes a framework within which there is significant contrast at equivalent positions. A Duna example, involving yari, the special word for 'cassowary' discussed above, is:

yusi yese yari no neya neyana nia

isuku asaka yari neya neyana niao

wale walu awuale yari neya neyana niao-o

the cassowary of Yusi Yese, I do not eat it,

the cassowary of Isuku Asaka, I do not eat it

the cassowary of Wale Walu Awuale, I do not eat it (Stewart and Strathern 2005:90-92, line nos. 65-67)

Similarly, a fragment of a tindi pii quoted by Lacey (1975:68-69) begins:

kaimini paina mende pea

paina paina mende pea

lyange tale kukupa paina mende pea

The words paina mende pea conclude the first eight lines of the text. The ninth line is:

lyange tale kuku paina mende peaki lalo ongo pilyamoo

Here a variation on paina mende pea is followed by lalo ongo pilyamoo, a phrase that marks the completion of a structural element that Lacey calls a "stanza," after which the performer pauses. During this pause "a member or members of the audience may utter brief comments or words of praise or encouragement to the performer" (ibid.:69).

Similar examples of parallelism are found in Huli bi té:

biruwa bai balu mondo biya

bayali balu mondo biya

limbiya balu mondo biya

limbai balu mondo biya

duliya balu mondo biya 
when he sat down, he killed a bai frog and fed it to them

he killed a bayali lizard and fed them

he killed a limbiya lizard and fed them

he killed a limbai rat and fed them

he killed a duliya lizard and fed them (Pugh-Kitingan 1981:735)

Finally, as an example of parallelism in a Karinj enj:

\section{Kulwap nak hal amu homolangel pisa la \\ Ipilpap nak hal amu homolangel pisa la \\ Ipil holal nak hal amu homolangel pisa la}

the boys/men from Kulwap came to compete for her

the Ipilpap boys/men came to compete for her

the Sangai boys from Ipili came to compete for her (Reithofer 2005:It. 7)

Further examples of parallelism are presented and discussed in chapter 10 from Karinj enj sung tales, in chapter 4 from Duna pikono, chapter 6 from Huli bi té, chapters 8 and 9 from Ipili tindi, and chapter 11 from Ku Waru tom yaya kange. ${ }^{9}$

Another special feature of the language of sung tales is the use of vocables, particularly in line- or section-final position. In the absence of a vocable, the final vowel of a word may be sustained. Stewart and Strathern (2005:88) note that each "notional line or segment of song" in Duna pikono "ends with the vocables o-o-o, dying off at the end of the segment and often answered by a noise of appreciation from the audience." The importance of vocables in defining a line of text has been described by Rumsey (2005:53) for Ku Waru tom yaya kange and Strathern and Stewart (2005b:216) for Melpa kang rom. Line-final vocables are also heard on recordings of Ipili tindi and Karinj enj. Aside from sung tales, sustained final vocables are a distinctive feature of Hagen oratory, that is, Melpa el ik (Strathern 1971:120, 182, n.1) and Ku Waru el ung (Merlan and Rumsey 1991:98-99). Many Ku Waru tom yaya kange have vocables appearing both at the end and in the middle portion of each line (Niles 2007:112-13; this volume). From the materials that have been examined so far, this combination of vocables appears to be unique to that region.

9 Parallelism is an example of a feature that, although common to sung tales, is by no means confined to them. It is a common feature of song texts, both within the region of sung tales: e.g., Ipili (Ingemann 1968), Duna (Stewart and Strathern 2005:88), Melpa (Strathern and Stewart 2005b:208-9; Niles, this volume); Karinj (Reithofer 2005), Enga (Talyaga 1973); and beyond: e.g., Wiru (Paia and Strathern 1977:6, 118-21), Central Buang in Morobe Province (Hooley 1987:74-75), Manambu in East Sepik Province (Harrison 1982:18-21), Kiwai in Western Province (Landtman 1913:290-303, 309-11), and Asmat in Papua province of Indonesia (Voorhoeve 1977:22). Indeed, parallelism is one of the most commonly occurring features in poetic genres around the world (Jakobson 1960; Fox 1977). 
Vocables do not seem to be as prevalent in Huli bi té, but the regular interjections by the audience of $\underline{\dot{e}}$ 'yes' at the end of lines or sections have a similar structural function. The importance of these interjections is apparent in the warning occasionally given by performers before they begin: "You say $\underline{\underline{e}}$ or my parents will die!," thereby ensuring that children pay attention (Pugh-Kitingan 1981:332).

\section{The music of sung tales}

All types of Highlands sung tales are presented using pitch patterns that are different from those of normal speech. In all areas, text is generally set syllabically to the melody, that is, with one syllable per pitch. Exceptions tend to occur at the end of phrases and are noted below. Only in the Hagen area is an isometric, binary melody repeated over and over until the story is completed (e.g., Rumsey 2001:212; Niles, this volume). Lembena tendi pii melodies are also sung to a definite pulse, but melodies do not appear to be repeated. As little work has been done on tendi pii, not much more can be said about this aspect of their structure.

Pugh-Kitingan is one of the few researchers to have focused on music in the region. In many forms of Huli music, the three tones of the language (highfalling, mid-level, low-rising) are fundamental in determining melodic shape; similarly the rhythm of the performance is related to speech:

There is no underlying pulse in Huli music; rhythm and form are determined by the structures of the word, sentences, and verses articulated. The pace of articulation in Huli music is as rapid as that of Huli speech. (Pugh-Kitingan 1984:96)

Melody is generally dominated by speech-tone. This domination is so great that Huli melodic movement appears to derive its essential motivation from the tonal patterns of the words and lines articulated. Language is thus as important in influencing melodic structure as it is in determining rhythm and form in Huli music. (ibid.:118)

Huli bi té are no exception. Pugh-Kitingan concludes that

speech-tone is the primary determinant of the melody with sentence terminating intonation producing the movement to the middle pitch at the end of lines. As in other genres of Huli music, rapid articulation sometimes causes adjacent words of the same speech-tone to share a tonally significant melodic shape. Where passages are based on a single pitch, slight fluctuations sounding about a quartertone from this pitch may indicate speech-tone. Lines also feature the purely melodic figure of a falling interval between outside pitches, which often contradicts the speech-tones of the words with which it coincides. (Pugh-Kitingan 1981:349) 
Microtonal variations in pitch are also reflected in the melodies of $\mathrm{Ku}$ Waru sung tales, a language that also has a tone system, albeit rather simpler than the Huli one (Rumsey 2007). And, as noted above, tom yaya kange are sung to binary melodies, rather than having a melodic shape largely dictated by speech-tone.

In an initial analysis of examples of Ipili tindi by Niles, only three different pitches are used, having the intervallic relationship of D, C, and B. Sung phrases, that is, the sung portion between breaths, use any of these pitches, but consistently alternate in ending on a $\mathrm{C}$, followed by a phrase ending on $\mathrm{B} .{ }^{10}$ (Note that such an alternation does not appear to have any relation to the binary melodies characteristic of Hagen sung tales: aside from these phrase-final notes, no other pitch transposition is involved.) The use of three pitches and the nonrepeating nature of each phrase preceding the final pitch strongly suggest a similarity to Pugh-Kitingan's description of Huli bi té. Furthermore, Ipili also has a word-tone system, like Huli and other members of the Engan group of languages described below. But whether this melodic movement is dictated by speech-tone or is independent of it is not known.

Written descriptions of musical characteristics are usually much more general, if included at all. Lacey (1975:59) notes that performers in the Lagaip and Maramuni (Malamuni) regions of the Enga language area have a reputation for producing some of the most renowned performers of tindi pii. The "greatest and most beautiful creations of these forms have the qualities called tipalya kondenge or toma lenge. Such phrases refer to these performances as being a blend of beautiful rhythmic cadences and beautiful language." Elsewhere, he notes that these terms are used by Yandapo and Taiato (Tayato) speakers to describe performances that are "flowing like water and sounding like music and song" (ibid.:xxi). Yet, how is this realized? Until further work is done on the musical aspects of both tindi pii and songs, the answer is not apparent.

Initial analyses by Niles suggest that Enga tindi pii employ variable rhythmic values, a descending melodic shape for phrases, and a general lack of a prominent pulse. Phrases appear to end on either of two tones, a step apart, but not with the regularity in alternation described for Ipili above. Additionally, final syllables may end on a two-note melismatic descent, rather than just a sustained tone. Lastly, although the rhythm generally seems to mimic spoken speech, there are sung phrases in which the rhythms appear to be more "regular" and the melodic movement follows more discrete steps. These phrases are followed by longer breaths (e.g., about eight seconds, instead of breaths lasting less than a second) and appear to recur in a performance. Perhaps these are the ends of "stanzas" noted by Lacey and described above.

10 Successive phrases, alternately ending on one or another pitch spaced a step apart, are also a feature of some performances of Karinj enj (see chapter 10). 
Karinj musical phrases also tend to initially undulate and then descend to the lowest pitch, which will then be sustained to conclude the phrase. Each phrase follows this pattern, ending on the same lowest pitch. The total range of pitches used is primarily a perfect fourth, with some higher pitches used occasionally. There does not appear to be a prominent pulse; rather, rhythmic values are highly variable, perhaps imitating spoken language. However, phrases ending alternately on tones a second apart were also heard in a performance of a Karinj enj by Josep Haip, during the Kefamo conference in 2006, thus demonstrating some linkages with Ipili and Enga genres (see chapter 10).

After noting that Duna pikono structure is in "clumps of phrases rhythmically juxtaposed, in which lines can be discerned but in practice run into each other," Stewart and Strathern (2005:89) note that a "downward trend of the voice of the performer indicates either a line ending or the ending of a clump of the kind we have just noted, or both." Consistent with the latter description, though expanding considerably upon it, Gillespie and San Roque in chapter 3 present an elegant analysis of the pikono musical-cum-textual line as bipartite in structure, consisting of a "descent" section followed by a "ground" section. In chapter 4, Sollis further explicates the structure of the pikono line and the relation between successive lines, showing that it often displays a kind of musical parallelism, and that there is an interplay between that and the parallelism across the associated lines of text. Further discussion of the musical aspects of Duna pikono is given by Chenoweth (1969), discussed below in the literature overview.

Preliminary analysis by Niles of examples of Bogaya kesa (recorded in 2003 by Anna Lockwood) shows a range of pitches extending over an octave. Phrase length is highly variable. While phrases tend to descend, sustained notes at various pitch levels, often involving short melismas to a lower pitch, are common. Similar comments can be made about examples heard of Hewa sung tales (recorded by Jessica Kemp in 2003), with the addition of phrasal sections of even beats, interspersed between those of rhythms seemingly reflecting spoken language.

As these general comments indicate, much more needs to be explored about the music of sung tales.

\section{Related genres not considered sung tales}

If sung tales share most of the features listed above, it is also important to consider genres that might also appear to share some of them, but differ in others and are therefore excluded from our focus. Note that some of the elements mentioned below that exclude certain performances from our definition of sung tales in the Highlands may be quite common in sung-narrative genres in other parts of the world. 
For the Kamano of Eastern Highlands, Berndt (1992:111-15) describes a type of story called kinihera, told by male or female performers in formal storytelling sessions in a special house at the start of the rainy season. These tales are told around an oven of edible leaves to encourage the growth of garden crops. In addition, Kamano also perform dramatic enactments (krina) of various kinds, some based on kinihera. Yet, in spite of various contextual similarities, there is no indication that kinihera are performed in a special way other than a normal speaking voice. The same is true of many other areas with highly developed storytelling traditions.

There are numerous examples of long textual performances that are "sung," but which also must be excluded from our category of sung tales. For example, Iatmul sagi performances in the Middle Sepik may last over sixteen hours, and formal ceremonies centring on clan members require such performances (Spearritt and Wassmann 1996; Wassmann 1991). Various sections of sagi involve solo or group singing, always accompanied by a drum and split-bamboo beater, and occasionally the playing of flutes and voice modifiers. If such instruments are used, they are played in an area screened off from the other performers. The long sung texts relate the migration of ancestors of a particular clan. Long series of paired names must be remembered - a very considerable task - and words considered archaic are common. The often esoteric meaning of the texts is known to only a few elders. Lines of text end in vocables and much parallelism is involved. While other men, women, and children listen to the singing, no one tries to enter the screened area; access is restricted to a very few men. Women may dance in the outside area. From this short description, one can see that there are many features shared with sung tales as discussed in this volume. However, the use of instruments, dance, and unison singing differs from Highlands sung tales. ${ }^{11}$ Furthermore the migration of clan ancestors related in sagi performances and the esoteric nature of such texts make them thematically very different from Highlands sung tales, taking them out of the realm of "entertainment."

Landtman (1913:289-301) reports Kiwai "serial songs," some of which comprise over fifty "verses." The texts often describe a "wandering" from Adiri, the land of the dead far to the west, moving gradually eastwards along the coast, "through the whole of the world known to the Kiwai people" (ibid.:295). Performances are associated with a variety of ceremonies conducted indoors. The singing is accompanied by dancing. A leader heads the procession and he introduces a text that is repeated by others until he feels it necessary to start a new text. Very long performances may be interrupted and continued on subsequent days. Hence, features such as the repetition of a line of text before introducing a new line, choral singing, dance, and the role of such serial songs in ceremonies, exclude them from the sung tales considered here.

11 Instruments do accompany epic song performances in other parts of the world (Reichl 2000:19ff.). 
The long Trobriand Islands historical poems, transcribed and translated by Kasaipwalova and Beier (Kasaipwalova 1978; Kasaipwalova and Beier 1978a, 1978b, 1979), have been considered by Strathern and Stewart (2005a:12-13) as genres quite similar to those under examination in this volume. While this is certainly true in relation to aspects of their poetic construction, judging from recordings of such poems in the Institute of Papua New Guinea Studies, it appears that some, if not all, of such historical poems are sung in unison by a group — something which precludes the kind of semi-improvised compositionin-performance that is a key feature of Highlands sung tales.

Returning to the Highlands region that is the focus of this volume, Enga sangai titi pingi nemongo share many features in common with sung tales. Used in sangai bachelor cults, ${ }^{12}$ titi pingi are described by Wiessner and Tumu (1998:39) as

sacred poetry that describes the series of transactions by which a cult's sacred objects were purchased from another clan of high repute, brought secretly to the cult house after perilous journeys by night, and passed on through the generations. At each step of purchase or transmission, new lines or verses are added. Recitations can last up to thirty minutes, albeit with much repetition. Only ambitious and capable young men learn the poetry in its entirety; most remember only the fragments that contain essential historical information.

Wiessner and Tumu (ibid.:404-10) also provide a transcription, translation, and interpretation of seven verses of a thirteen-verse titi pingi. We exclude titi pingi from our category of sung tales because of their focus on the transmission of sacred objects. While this may be considered a journey of sorts, it is not a narrative told for entertainment, but to recall the history of sacred objects and their power to transform young men, with each clan or subclan having its own story (ibid.:230-32; also see Gibbs 1990).

The following description of Fasu (Southern Highlands) mano ho-ra, however, sounds very much like a sung tale, through the interaction with the audience (as found in sung-tale traditions to the west of Hagen), the special mode of delivery, the addition of the vocable $-o$, repetition, etc.:

A legendary narrative known as mano ho-ra 'man speak customary' is characterized by two final verb suffixes ... All stories involve interaction between 'good' and 'bad' characters.

12 Apparently originating in the central Enga, sangai diffused eastwards and is called sandalu in the Layapo area. Although similar to sangai, there were some important differences in sandalu, notably, for our discussion, "the recitation of poems for the sacred objects was either omitted or greatly abbreviated" in the latter (Wiessner and Tumu 1998:238). 
The storyteller did not want to tell these stories into a tape recorder. He had to bring his children along and tell them the story. The reason became evident. Every now and then the story teller interjected a question to the audience: 'Now what do you think of that'. This occurred at climactic points when something was grandiose beyond explaining. Sometimes at the beginning of the story there was a rhetorical question asked of the audience.

These stories are told in speech-song 'Sprechstimme' 'speaking voice'. The story is not sung, and is not spoken, but has the character of both being delivered in a manner half way between. Each character in the story has his own voice quality. Hence quotes are not marked in formulaic fashion. The main characters which appear in nearly all the stories are an old man, an old woman, a young man and a young woman. Sometimes there are children and sometimes animals. The characters are known by the voice quality and by story teller.

To the verbal suffixes of dependent clauses - $O$ is added. In the speechsong style this vowel can be drawn out and adds to the rhythm of the speech-song style. This style also makes for much repetition, that is, the same thing is said again and again.

The stories are hard for the naive listener to comprehend. There is much implied information. Each story has a moral at the end. This is not explicitly stated, but is definitely implied. Because these stories are stated in code-like terms, an example will not be given. These stories hinge between speech and song. (Loeweke and May 1980:95-97)

In May and Loeweke's subsequent Fasu dictionary, the only reference we have been able to find to something similar is mano hosie 'tell the mano legend' (May and Loeweke 1981:73-74), listed under the verb horakā 'speak, sing', however, we are not given further information here as to what the "mano legend" is. ${ }^{13}$ Subsequent correspondence with anthropologist Kurita Hiroyuki (emails to Niles, 10 October 2006, 23 October 2006), who was very familiar with the linguistic work of May and Loeweke for his own research with the Fasu, has clarified questions relating to this genre: the teller of mano ho-ra adopts different voice qualities to represent different characters, but otherwise the presentation resembles normal speech.

13 According to May and Loeweke's Fasu dictionary, Māno is the name of a village, while, as a noun, máno is a 'title given to a boy child' or, as an adjective, has meanings such as 'small, young, new' (May and Loeweke 1981:145). 


\section{Terminology}

Researchers often have to face difficult decisions in deciding how to translate terms from one language to another, particularly if features relevant to the sense of a term in one language do not neatly correspond to those in another. As a result, some authors may translate the name for a certain type of narrative tradition as "myth," others as "legend," "folktale," or simply "story." Such issues become even more of a concern in comparative studies involving many languages. Here, researchers must use certain terms that may quite adequately describe a genre in one region, but not be quite as appropriate in a different one. When the genre being considered does not have a convenient name in the language of writing (English, in this case), the difficulty is further compounded. ${ }^{14}$

The genre we are calling "sung tales" has been given a variety of names by different authors - for example, "ballads," "epics," etc. Indeed, the name of the ARC project concerning them used "chanted tales." While some researchers were attracted to this name, particularly because of the implication that such performances are also enchanting compositions (which they certainly are), ethnomusicologists have raised concerns over the use of the word "chant" (also see the discussion by Pugh-Kitingan in chapter 6). ${ }^{15}$

But is "sung narrative," "sung story," or "sung tale" any better? Certainly all genres considered here are narratives or stories, but are they sung? We argue that one of the features that distinguishes this genre from spoken narratives or tales is the special mode of delivery used by the performer. But if this delivery cannot be called "chanted" or "spoken," is it "sung"? For the genre of sung tales, there is greater variation in the pitches used than in normal speech, and there often does seem to be a melodic framework in which sung tales are presented. However, if

14 Some of these issues of terminology have been considered by Reichl (2000:12-13) and Strathern and Stewart (2005a:16-18).

15 For example, in the volume of the Garland Encyclopedia of World Music devoted to Australia and the Pacific, the glossary defines "chant" as "recitational singing, often on one or two tones, with rhythms deriving from those of the words" (Kaeppler and Love 1998:1027). While some of the sung tales considered here might be considered "recitational" in nature, with a limited use of pitches and with rhythms derived from spoken language, there are many examples where this is much less true, unclear, or totally inaccurate. But objections to the word "chant" go beyond just an inadequate characterization of musical features. "Chant" often has pejorative associations: "As a handy label for Oceanic song, the word chant appears in all forms of literature, in all periods, usually meaning that the described music did not have the tonal variety of European music" (Love 1998:36). Furthermore, "outside observers often distinguish less melodically varied and more rhythmically word-dependent renditions by a term like chant, which, for the more melodically varied and less word-dependent rendition, they contrast with a term like song ... Since the introduction of the words chant and song, many [Pacific] cultures have used these terms to categorize the old and the new" (Love and Kaeppler 1998:321). None of the contributors to this volume believe that the traditions considered in it are inferior to any other traditions in the world. And, as illustrated in some of the articles here, there can be many parallels between the melodies used for sung tales and those used for other genres more readily recognized as song. In Papua New Guinea at least, "chant" and "song" are not used to differentiate old and new traditions, and we do not wish to encourage such a usage. For all these reasons, there are difficulties in using "chant" as either a noun or a verb for these traditions, despite their undeniable ability to enchant. 
we look for evidence in the verbs used to indicate the performance of sung tales in the different languages concerned - in the expectation, for example, that they might be different from those used for the normal telling of stories or even the same as those used for singing-we often find that it is unhelpful in resolving such a query. In many traditions, there is no special word for 'to sing', rather 'to say' is used. And there appears to be no special verb used anywhere to describe the performance of sung tales as opposed to the telling of any other story or the "saying" of a song. For example, in the Hagen area, the verb used to describe the telling of all stories, including sung tales, is one that when used by itself means 'to hit'. While this may seem particularly appropriate for Hagen sung tales considering their fast, metric presentation, a kange story told in a normal speaking voice is also 'hit'.

The word "ballad" might appear to be more apt in emphasizing aspects of narrative, popular themes, and the importance as entertainment, but the term seems to be usually applied to performances using strophic texts, that is, a changing text set to a repeating melody (Bronson 1980). While this might be an appropriate description for some areas in the Highlands, in others, such a repeating melody is absent.

There are also certain similarities between the sung tales considered here and the long epics often associated with traditions more distant geographically and/ or chronologically. Reichl (2000:14) notes that epic poetry is narrative, metric, often of great length, and archaic. Some of these features are also typical of sung tales. Yet, the heroic, often martial, nature usually associated with epics (ibid.) is not appropriate for all the Papua New Guinea traditions. Even here the boundaries between the terms for such genres are quite fluid, since "certain types of ballad might also be classified as epic song" (Anon. 1980).

Although preferring to use "ballads" in reference to the Melpa kang rom and Duna pikono they have studied, Stewart and Strathern (2002a) also refer to them as being "sung" (p. 122) or "chanted" (ibid.) and as "chanted epics" (p. 135). Such variation indicates some of the difficulties in finding appropriate English terminology.

Hence, while no one term seems totally adequate, and all could be argued to have some sort of validity, "sung narrative," "sung story," or "sung tale" could be considered preferable in emphasizing the importance of a narrative and its presentation in something other than normal speech, possibly more akin to singing. Nevertheless, we have not imposed conformity of usage in the contributions here. Rather, authors use whatever terms they feel most appropriate and comfortable with. 
In the introduction to the volume he has edited called The Oral Epic: Performance and Music, Karl Reichl discusses some features of sung stories, particularly in Europe and Asia. He notes a common contrast between melodies that are stichic (the same melody for every line of poetry) and strophic (melodies that require more than one line of poetry) (Reichl 2000:4). While some of the melodies considered here could probably be called strophic, stichic is certainly an inappropriate description for the remainder where there may be considerable melodic variation between lines. Reichl also points out that "the musical aspect is of importance, at least when it comes to properly understanding the metrical structure of an orally performed poem" (ibid.:10). Although he is here referring specifically to the ambiguous nature of the metre of the verse in Russian epic called bylina, the same could be said even more strongly for Melpa kang rom and $\mathrm{Ku}$ Waru tom yaya kange. In these Hagen cases, the melody absolutely determines the metric structure of the poetry. Yet, in other examples of sung tales considered here, this is not so. Generalizing further, Reichl observes that

as narratives, epics tell a story, i.e., the emphasis is on words and their meaning and not (primarily) on music. If in the light of our discussion of (poetic) metre, music fulfils a quasi-metrical function, i.e., that of helping to group the words into rhythmical, repetitive units, then music plays primarily a structural role. And it follows from these assumptions that this type of melody will be fairly simple, modelled on the inflections of speech rather than developing into full-fledged song. (Reichl 2000:15)

But what are the boundaries between a melody "modelled on the inflections of speech" and "full-fledged song"? Rather than tackle such a thorny issue, it seems better to conclude that "the performance of epic adapts itself to the musical styles current in a particular region" (Reichl 2000:20) and that, aside from structural issues, singing enables the performer to make his or her voice carry further and increase the audibility of the tale (ibid.:21).

\section{Distribution of sung-tales genres and languages}

Figure 2 shows the areas in Southern Highlands, Enga, and Western Highlands provinces where sung tales are found. Vernacular names for sung tales are given in brackets beneath language names in bold italics. Adjacent areas where sung tales are absent or for which data are inconclusive are also shown. In such a mapping, the absence of a feature is just as important as its presence. Distributional mapping is particularly difficult in this case, however, in that one cannot always assume that no mention of sung tales in the literature means absence. For example, the extensive early ethnographic materials written by missionaries on the Hagen area make no mention of kang rom. Nevertheless, 
consultation of the existing ethnographic literature on the area, coupled with queries to individual researchers and, more generally, on Internet email lists suggest that most of the absences on the map are valid.

In spite of this, the map should only be considered a conservative indication of the distribution of sung tales. For example, such a genre might be present in some of the other languages in Angal-Kewa subgroup - that is, particularly in areas where closely related languages are associated with such a genre. ${ }^{16}$ To date, however, our knowledge remains incomplete. One of the purposes of this volume is to stimulate research in such areas of uncertainty.

Is there any relationship between the genetic grouping of languages here and the presence or absence of sung tales? According to the most recent classification of languages in this region of Papua New Guinea (Ross 2005; Pawley 2005), many of these languages belong to the Trans New Guinea family - a large group of over three hundred languages spread across the whole island (see Ross 2005:34, map 5). Throughout much of this area, no sung tales are found. Hence, our focus here is primarily on the consideration of lower order groups and subgroups. ${ }^{17}$

Within the Trans New Guinea family, Ross (2005:35, table 7) has identified a number of major groups of languages, some of which are represented on figure 2 . The list in figure 3 , which should be examined in relation to figure 2 , illustrates the distribution of sung tales arranged according to language classification. The name of the genre, where known, is included. Absences for entire groups or subgroups are noted. Languages belonging to the groupings that appear on the map are specified.

The only first-order group of the Trans New Guinea family in which all language members have sung tales is Duna-Pogaia, consisting of only two languages, with Duna speakers far outnumbering those of Bogaya. In the much larger Engan group, the Huli language (a subgroup itself) and most languages of the Enga subgroup also have sung tales, with fewer representatives in the Angal-Kewa subgroup. Finally, the only subgrouping of the Chimbu-Wahgi group known

\footnotetext{
16 A work of fiction concerning the Imbonggu area by Linda Harvey Kelley (1984:43-44) contains a scene where a woman tries to comfort her daughter, so the mother begins to "sing a story." While the story is madeup (Linda Harvey Kelley, pers. comm. to Niles, 9 March 2011), the opening fragment is certainly reminiscent of sung tales in the Hagen area, and most lines of the English text end in vocables. However, the vocable most often used (-iyo) has not previously been heard in Melpa kang rom or Ku Waru tom yaya kange. Furthermore, -iyo-iyo-iyo-iyo-iyo is also used as a replacement for a line of text. While we have not previously encountered this in sung tales, it is a common feature of songs in the Hagen area, as Kelley herself illustrates (ibid.:35-36). Perhaps these features are a bit of poetic licence or misremembering on her part, or perhaps they are distinctive elements of performance practice in the Imbonggu area. Certainly further research is needed to clarify the situation. Aside from this representation in fiction, Imbonggu speakers confirm that sung tales are performed in the region; as such, their presence is shown in figure 2.

17 For the sake of simplicity, throughout this discussion first-order groupings of languages within a family are called "groups"; lower level groupings within these groups are called "subgroups."
} 
to have sung tales is the Hagen subgroup, in which all languages have them. Significantly, all other first-order groups of the Trans New Guinea family lack sung tales, at least according to present knowledge.

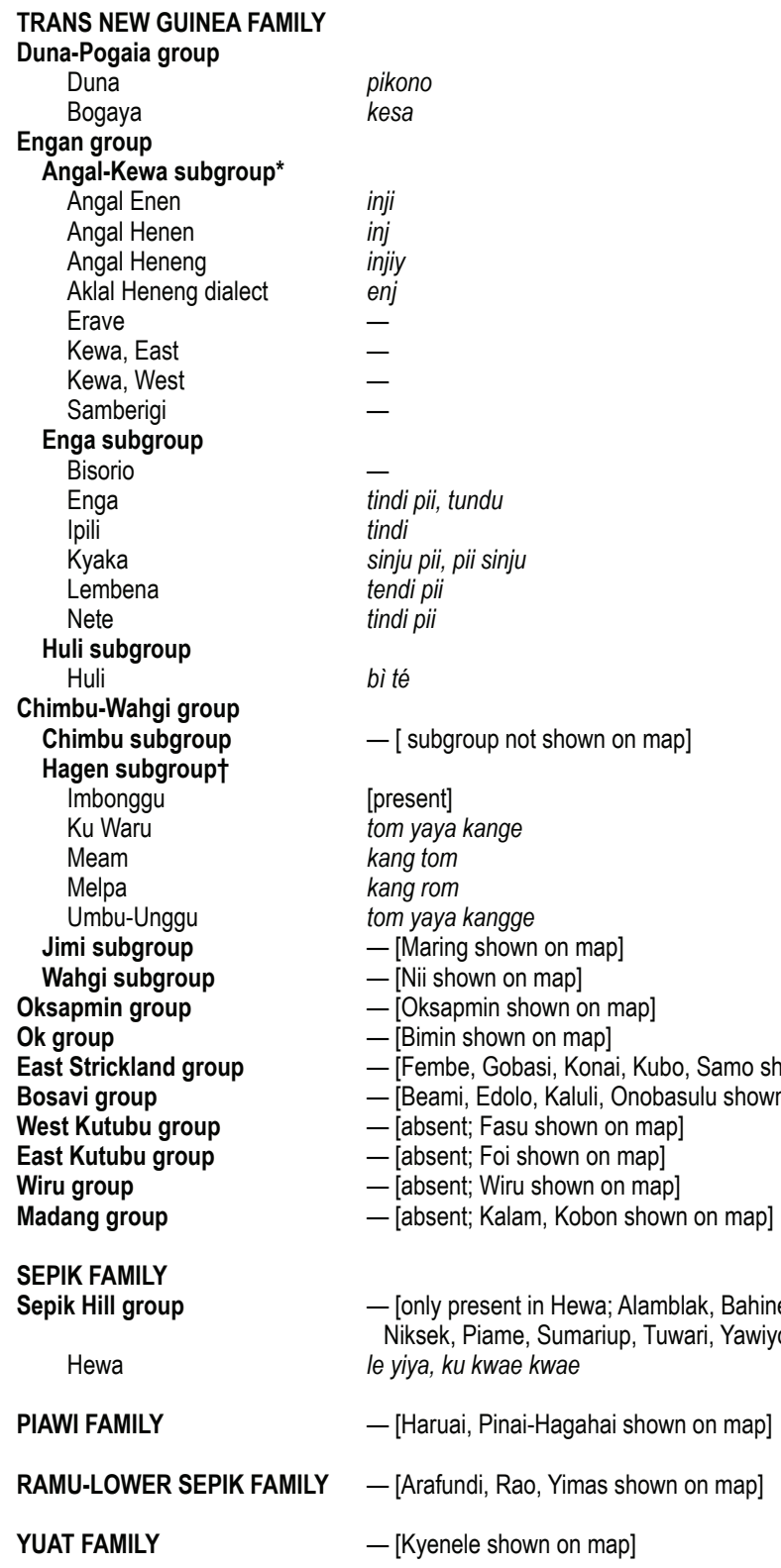

Figure 3. The distribution of sung tales arranged according to language classification. (* The names of Angal languages are based on information supplied by Hans Reithofer; $\uparrow$ The names of Hagen languages are based on information supplied by Rumsey.) 
The only non-Trans New Guinea family language in which sung tales are known to be performed is Hewa, a member of the Sepik Family, Sepik Hill group. Other languages belonging to this group are mostly located to the north of Hewa.

Hence, considering only first-order groups of the Trans New Guinea family, we find that sung tales are particularly associated with Duna-Pogaia and Engan languages. Within the latter at lower divisions, sung tales are found in Huli, most of the Enga subgroup languages, and in all of the Angal languages of the Angal-Kewa subgroup. Within the Chimbu-Wahgi group, sung tales are only found in the westernmost subgroup, Hagen. These relations and mappings might be taken to suggest an origin somewhere in parts of Southern Highlands or Enga and diffusion from there, although the evidence from language groupings is by itself not particularly compelling, since language difference apparently presents no obstacle to the spread of such a genre in this region. ${ }^{18}$

Within the languages associated with sung tales, there are some obvious cognates of vernacular names for the genre. Enga tindi pii, Kyaka sinju pii or pii sinju, and Lembena tendi pii clearly cluster together. The pii part of these forms means 'talk/speech, language, word' (Lang 1973:85) ${ }^{19}$ and is also cognate with the first word in Huli bi té 'talk/words story' (Pugh-Kitingan 1981:332). Enga/Ipili tindi, Angal Enen inji, Angal Henen inj, Angal Heneng injiy/enj, Kyaka sinju, and Lembena tendi may also be cognate with East Kewa lidi/lindi and West Kewa iti. The Kewa terms refer to a type of story, generally believed to be fictional (LeRoy 1985). Anthropologists who have worked in the Kewa area have not reported sung tales there, although Summer Institute of Linguistics worker Karl Franklin, believes that such stories can be "chanted, often in a falsetto voice" (email to Rumsey, December 2002). However, in the absence of recordings or further information, it remains unclear whether these are examples of sung tales or not. Nor would the mere presence of a cognate term for any of the ones listed above for the Duna-Pogaia or Engan groups necessarily attest to the presence of sung tales, since none of those terms refers only to sung versions. Such evidence would be more telling within the Chimbu-Waghi group, since the known terms from there refer specifically to sung versions of kange tales.

\footnotetext{
18 A relevant factor is that there is generally extensive bi- and multilingualism in border areas between the languages. For discussion of a typical example in the Southern Highlands and reference to literature on others within the region, see chapter 10 .

19 Frances Ingemann (email to Alan Rumsey, 26 February 2008) reports that among the Ipili, tindi is used to refer to stories and tindi pii refers to the special vocabulary used in them. From this it would seem that Ipili pii at least in this context has a more restricted sense than Enga pii or Huli bi, referring specifically to word(s).
} 
Although the Duna language is genetically only very distantly related to Huli, ${ }^{20}$ Duna pikono are similar in some ways to Huli bi té, thus showing that language similarities or differences do not necessarily reflect comparable degrees of relatedness in other cultural features. As another example, Lembena tendi pii appear to be similar to the Hagen style of sung tales in the use of melodies involving a very definite, regular pulse; however, the melodies do not appear to be repeating, binary ones. The Lembena language is part of the Engan group, whereas Hagen languages are part of the Chimbu-Wahgi group.

\section{Overview of main publications on sung tales}

The first published reference to a genre of sung tales appears to be Glasse's mention of Huli 'pi te', which he describes as 'folk stories' in contrast to mana 'myths' (Glasse 1965:33). ${ }^{21}$ However, he gives no indication of any special manner of presentation, so he may not have heard them performed as sung tales; it is only from the subsequent work of other researchers that we know them as such.

Using materials collected by Summer Institute of Linguistics translators Dennis and Nancy Cochrane, ethnomusicologist Vida Chenoweth differentiates three Duna singing styles: that used for dance songs, the sprechstimme of "chant," and that for "the intimate narrative or "ballad" "(Chenoweth 1969:219). ${ }^{22}$ Although the Duna term for them is not specified, the identification of the latter style as sung pikono is obvious from her description (pp. 224-27). Focussing on melodic and rhythmic aspects of performance, Chenoweth also notes that: the melodic form of such ballads is dependent on the text (p. 224); ballads vary considerably in length, a 74-line one being described as one of as the longest she has found in New Guinea (p. 225); ${ }^{23}$ textual parallelism is common, with word substitutions occurring at the beginning of lines, rather than the end (pp. 225-26). Chenoweth

\footnotetext{
20 "Genetic" distance is measured in terms of the incidence of shared features presumably resulting from retention from a common proto-language, as per the standard comparative method used within historical linguistics. Not considered in such an account are similarities resulting from "borrowing"- the diffusion of words and other features from one language to another resulting from interaction between people who speak both of them. There has evidently been a considerable amount of such diffusion from Huli to Duna, resulting in extensive shared vocabulary (Voorhoeve 1975:395). This is consistent with the fact that there has apparently been considerable cultural diffusion of other sorts between Huli and Duna, presumably including that which has resulted in the similarities between Duna pikono and Huli bì té.

21 See chapter 6 where Pugh-Kitingan discusses Glasse's incorrect gloss of mana as 'myths'.

22 In a later summary of the findings in this article, Chenoweth (2000) states that her analysis was done in 1968 and refers to materials collected in 1964 by the Cochranes. Chenoweth further notes that "ballads follow speech rhythm whereas sing-sings ... follow the rhythm of the dance" (p. 179).

23 Actually a footnote from Nancy Cochrane reveals that Duna people commented that this was one of the shorter versions since it was recorded when it was cold (Chenoweth 1969:225, n. 11). By way of comparison, of the three Duna sung pikono performances that have been transcribed and translated in full by Lila San Roque, all by different performers, one runs to 424 lines, another to approximately 1,200, and another to approximately 2,500 .
} 
(1969:226-27) then outlines some plots of pikono and concludes by highlighting musical contrasts in the three styles of singing surveyed. This appears to be the first attested recognition of a genre of sung narratives as something distinct from song and storytelling, but related to both.

Following a brief mention of pikono by Modjeska (1977:107, 322), knowledge of this genre has been much expanded through the research and publications of Andrew Strathern (who first recorded pikono in 1991) and Pamela Stewart (e.g., Stewart and Strathern 2002a; 2005; Strathern and Stewart, this volume), Haley (2002), Gillespie (2010), and San Roque (Gillespie and San Roque, this volume). Some recorded excerpts of pikono accompany Strathern and Stewart (2000). Sollis $(2006,2010)$ considers modifications of word tone in Huli and Duna sung tales, and their relation to the melodies in which the tales are performed.

Writings on various regional sung-tale genres by a number of authors started to appear in 1975. Pugh-Kitingan began her examination of Huli bi té in an Honours thesis (Pugh 1975:10-30) and, after later research, further considered the genre in her work on Huli vocal and instrumental genres (Pugh-Kitingan 1981:332-50, 710-87; 1984:115-16; 1998). This was followed by Goldman's anthropological work (Goldman 1983, 1998) and the linguistic research of Lomas (1988). Lomas was also a co-compiler of Ngodehondo bi lamiy $\underline{a}$ (Alexishafen: SVD Press, 1977), which includes "Misa iba gana," a setting of the Catholic mass based on traditional Huli expressive genres, including bì té.

Also in 1975, Lacey wrote extensively about Enga oral traditions, devoting considerable discussion to tindi pii (Lacey 1975:59-60, 68-73, 264-67, and elsewhere); he also notes that the Laiapo (Layapo) name for sung tales is tundu (p. xx). Lacey includes a listing of "Collections of Enga Oral Sources in a Written Form," which contains references to at least eight manuscripts concerning tindi pii (pp. 313-14). In a subsequent article, Lacey (1979:194-96) presents the legend of Pandakusa. Although it is not specifically identified as tindi pii, his comments on the context, audience interaction, and evaluation of it "like running water, [which] flowed as a creation rich in music and wisdom" (ibid.:194) suggest that it is. Wiessner and Tumu (1998:26) consider tindi pii as myth, characterizing it as "free text, preferably told in rhythmic chant." They further explain that "when narrated by experts, [tindi pii] are recited in a poetic chant with repetitive rhythmic patterns and rhyme. Complex and colourful images are used to challenge listeners and hold their attention. A single myth can go on for over an hour, requiring extraordinary verbal skill on the part of the narrator" (ibid.:26-27).

To the west, Gibbs $(1975,1978)$ wrote on Ipili tindi, providing translations of stories and interpretations in two theses. He notes that "chanting stories is an achieved art mastered by few" (Gibbs 1975:102). Recordings of this genre were 
made by linguist Frances Ingemann beginning in the 1960s. In addition to one conference paper on Ipili courting songs (Ingemann 1968), she has compiled recorded examples of various genres for archival purposes (Ingemann 1987), from which one fragment of a tindi has been published (Niles and Webb 1987:Enga11). Research on Ipili tindi has also continued with the work of Biersack (1999).

Beginning his fieldwork in 1964 in the Hagen area, Andrew Strathern first recorded a Melpa kang rom in 1965. Although his first published reference to this genre appears to be in a radio script including musical examples prepared for the National Broadcasting Commission (1983:4), since that time he and Pamela Stewart have written in considerable detail about this genre, particularly since 1997 (e.g., Strathern 1995, 1998; Strathern and Stewart 1997a, 2000), leading to a book with a chapter devoted to the subject of ballads (Stewart and Strathern 2002a:121-45) and an edited volume on expressive genres in which they examine kang rom in their introduction (Strathern and Stewart 2005a:11-18) and in a separate chapter (Strathern and Stewart 2005b). Their work has considered such aspects of kang rom as poetic translation, plots, textual parallelism, and interpretation. A short extract of one kang rom, recorded by Niles and Strathern in 1982, has been published (Niles and Webb 1987:Western Highlands-5). Other excerpts of kang rom performances accompany Strathern and Stewart (2000).

To the southwest among the $\mathrm{Ku}$ Waru people, Alan Rumsey and Francesca Merlan began their fieldwork in 1981. Although they recorded some tom yaya kange in the early 1980s (Rumsey 1995), it became a main focus of Rumsey's work from 1997. Beginning with his 2001 article in which a full tom yaya kange text is transcribed and translated, Rumsey has written about this and other texts with respect to their metric, melodic, and poetic features in increasing detail (e.g., Rumsey 2002, 2005, 2006a, 2006b, 2007, 2010). His interest in the work of other researchers on sung tales prompted the preparation of an ARC grant proposal, which was accepted and has led to the project from which this volume has arisen (for details of which, see http://chl.anu.edu.au/anthropology/ chantedtales/). Although first exposed to and interested in kang rom and Melpa songs through fruitful collaborative research with Andrew Strathern beginning in 1982, Niles's involvement in the ARC project encouraged him to write about Hagen sung tales, particularly in comparison with other melodic forms in the area (Niles 2007, 2009). Michael Mel (2005) argues that Hagen sung tales are important vehicles for building a sense of community and of belonging in such a community.

In a collection of stories from the Kaugel (Umbu-Unggu) area, Lepi and Bowers (1983:5) observe that kange are "normally told in a quick, sing-song voice," but neither of them appears to have published more on this subject. 
Although a number of researchers have worked in the Mendi area, Reithofer appears to be the first to have written about sung tales from the region, based on his 1998-2000 research among the Karinj. The Karinj speak the Aklal Heneng dialect of Angal Heneng. Here enj are described as "origin myths, folk tales," in contrast to arman "remembered history, genealogies" (Reithofer 2006:19, fig. 1). Arman appears to be cognate with Melpa teman, Ku Waru temani, Ipili temane, and Erave ramani, and may also relate to Enga atome and Kyaka arome. All of these terms emphasize the more historical nature of the stories concerned, in contrast to the less historical nature of enj.

Information on sung tales in other regions is minimal. Missionary linguists Draper and Draper (2002:393) note Kyaka sinju pii or pii sinju as a "tale, story, legend, myth, folklore," distinct from arome pii "which is believed to be true" (ibid.). Obviously sinju pii and arome pii are cognate with Enga tindi pii and atome pii, respectively, but given that the latter can refer to spoken tales as well as sung ones, in the absence of sound recordings it remains unclear whether sinju pii are ever sung.

Summer Institute of Linguistics worker Paul Heineman has shared recorded examples of Lembena tendi pii with us, but has not done detailed work on them yet. Jerry Jacka has recorded sung tales in the Nete area (email to Rumsey, April 2003). Two ANU anthropology students recorded, transcribed, and translated sung tales during their fieldwork in the Southern Highlands Province in 2004: Jessica Kemp recorded Hewa le yiya 'clan narrative' and ku kwae kwae 'before story’ at Wanakipa; Anna Lockwood recorded Bogaya kesa at Ekali.

\section{Plan of the volume}

As in the discussion of plots and characters above, the order of exposition within the rest of this volume runs generally from west to east, beginning with Duna pikono (chapters 2-4), then moving to Huli bi té (chapters 5-6), Enga tindi pii (chapter 7), Ipili tindi (chapters 8-9), West Mendi enj (chapter 10), Ku Waru tom yaya kange (chapters 11-12), and Melpa kang rom (chapter 12). The final chapter (13) closes the circle by considering aspects of Melpa kang rom in relation to Duna pikono (and, for good measure, works from classical antiquity by Hesiod and Virgil). For most of these regional genres there are treatments from two or three different disciplinary perspectives from among the trio of sociocultural anthropology, linguistics, and ethnomusicology. In each case where those multiple perspectives are brought to bear, they are deployed not in isolation from each other, but in combination, providing insights that would not otherwise be possible. 
Furthermore the opening chapter to the Duna section, following up on this one, comes from a fourth perspective that very usefully complements all the othersthat of an insider from the Duna area with long experience as a research assistant and interpreter of the local lifeways to interested outsiders such as we expect will be the main readers of this volume. Since many of the points discussed by Kendoli with respect to pikono pertain in a general way to most or all of the other regional genres of sung tales discussed in this volume, his chapter can serve as a Highlander's-eye introduction to the whole volume, complementing the present one in that respect.

\section{Acknowledgments}

For their valuable comments on an earlier version of this chapter, we wish to thank Jacqueline Pugh-Kitingan, Hans Reithofer, Lila San Roque, Pamela Stewart, Andrew Strathern, and two anonymous referees.

\section{References}

Anonymous. 1980. "Epic Song." In The New Grove Dictionary of Music and Musicians, edited by Stanley Sadie, vol. 6, 22. 20 vols. London: Macmillan.

Berndt, Catherine H. 1992. "Journey along Mythic Pathways.” In Ethnographic Presents: Pioneering Anthropologists in the Papua New Guinea Highlands, edited by Terence E. Hays, 98-136. Studies in Melanesian Anthropology, 12. Berkeley: University of California Press.

Biersack, Aletta. 1995. "Introduction: The Huli, Duna, and Ipili Peoples Yesterday and Today." In Papuan Borderlands: Huli, Duna, and Ipili Perspectives on the Papua New Guinea Highlands, edited by Aletta Biersack, 1-54. Ann Arbor: University of Michigan Press.

1999. "The Mount Kare Python and His Gold: Totemism and Ecology in the Papua New Guinea Highlands." American Anthropologist 101: 68-87.

Brennan, Paul W. 1970. "Enga Referential Symbolism: Verbal and Visual." In Exploring Enga Culture: Studies in Missionary Anthropology, edited by Paul W. Brennan, 17-50. Second Anthropological Conference of the New Guinea Lutheran Mission. Wapenamanda: New Guinea Lutheran Mission.

Bronson, Bertrand H. 1980. "Ballad §I: Folk and Popular Balladry." In The New Grove Dictionary of Music and Musicians, edited by Stanley Sadie, vol. 2, 70-75. 20 vols. London: Macmillan. 
Chenoweth, Vida. 1969. "An Investigation of the Singing Styles of the Dunas." Oceania 39 (3): 218-30.

- 2000. Sing-sing: Communal Singing and Dancing in Papua New Guinea. Christchurch: Macmillan Brown Centre for Pacific Studies.

Denham, T. P. 2006. "The Origins of Agriculture in New Guinea: Evidence, Interpretation and Reflection." In Blackwell Guide to Archaeology in Oceania: Australia and the Pacific islands, edited by I. Lilley, 160-88. Oxford: Blackwell.

Draper, Norm, and Sheila Draper. 2002. Dictionary of Kyaka Enga, Papua New Guinea. Pacific Linguistics, 532. Canberra: Australian National University.

Fox, James J. 1977. "Roman Jakobson and the Comparative Study of Parallelism." In Roman Jakobson: Echoes of His Scholarship, edited by Cornelis H. van Schooneveld and Daniel Armstrong, 59-90. Lisse: Peter de Ridder Press.

Gibbs, Philip. 1975. "Ipili Religion Past and Present.” Diploma in Anthropology thesis, University of Sydney.

- 1978. "Kaunala Tape: Towards a Theological Reflection on a New Guinea Initiation Myth.” MA thesis, Catholic Theological Union (Chicago).

- 1990. "Titi Pingi: Theology of an Engan Praise Poem." Catalyst 20 (2): 117-36.

Gillespie, Kirsty. 2010. Steep Slopes: Music and Change in the Highlands of Papua New Guinea. Canberra: ANU E Press. http://epress.anu.edu.au/ steepslopes_citation.html.

Glasse, Robert M. 1965. "The Huli of the Southern Highlands." In Gods Ghosts and Men in Melanesia, edited by Peter Lawrence and Mervyn J. Meggitt, 27-49. Melbourne: Oxford University Press.

Goldman, Laurence R. 1983. Talk Never Dies: The Language of Huli Disputes. London: Tavistock Publications.

_. 1998. Child's Play: Myth, Mimesis and Make-believe. Oxford: Berg.

Haley, Nicole. 2002. "Ipakana Yakaiya: Mapping Landscapes, Mapping Lives; Contemporary Land Politics among the Duna." PhD dissertation, Australian National University.

Harrison, Simon. 1982. Laments for Foiled Marriages: Love-songs from a Sepik River Village. Boroko: Institute of Papua New Guinea Studies. 
Hooley, Bruce A. 1987. "Central Buang Poetry." In Perspectives on Language and Text: Essays and Poems in Honour of Francis I. Andersen's Sixtieth Birthday, edited by Edgar W. Conrad and Edward G. Newing, 71-88. Winona Lake, Indiana: Eisenbrauns.

Ingemann, Frances. 1968. "The Linguistic Structure of an Ipili-Paiyala Song Type." 6 pp. Paper presented at the 8th International Congress of Anthropological and Ethnological Sciences, Tokyo.

- 1987. [Cassette of Ipili music with notes]. IPNGS x87-096. Music Archive, Institute of Papua New Guinea Studies.

Jakobson, Roman. 1960. "Closing Statement: Linguistics and Poetics." In Style in Language, edited by Thomas A. Sebeok, 350-77. Cambridge, MA: Massachusetts Institute of Technology Press.

Kaeppler, Adrienne L., and J. W. Love, eds. 1998. Australia and the Pacific Islands. The Garland Encyclopedia of World Music, 9. New York: Garland Publishing.

Kasaipwalova, John. 1978. Yaulabuta, Kolupa, deli Lekolekwa (Pilatolu Kilivila Wosimwaya). Port Moresby: Institute of Papua New Guinea Studies.

Kasaipwalova, John, and Ulli Beier. 1978a. Lekolekwa: An Historical Song from the Trobriand Islands. Port Moresby: Institute of Papua New Guinea Studies.

. 1978b. Yaulabuta: The Passion of Chief Kailaga; An Historical Poem from the Trobriand Islands. Port Moresby: Institute of Papua New Guinea Studies.

\section{4 (2) (August): 47-48.}

Kelley, Linda Harvey. 1984. “Totopo-Tenth Wife.” Bikmaus 5 (4) (December): 21-87 (revised as: Toropo: Tenth Wife. Port Melbourne: Rigby Heinemann, 1995).

Lacey, Roderic. 1975. "Oral Traditions as History: An Exploration of Oral Sources among the Enga of the New Guinea Highlands." $\mathrm{PhD}$ dissertation, University of Wisconsin.

. 1979. "Heroes, Journeys and Change: Themes in Precolonial Religious Life in Papua New Guinea." In Powers, Plumes and Piglets: Phenomena of Melanesian Religion, edited by Norman C. Habel, 194-209, 220-21. Bedford Park: Australian Association for the Study of Religions. 
Landtman, Gunnar. 1913. "The Poetry of the Kiwai Papuans.” Folklore 24: 284313.

Lang, Adrianne. 1973. Enga Dictionary with English Index. Pacific Linguistics, C 20. Canberra: Australian National University.

Lepi, Pundia, and Nancy Bowers. 1983. "Kaugel Stories: Temane and Kangi." Oral History 11 (4): 1-145.

LeRoy, John. 1985. Kewa Tales. Vancouver: University of British Columbia Press.

Lewis, Neryl. 2007. "Conflict Vulnerability Assessment of the Southern Highlands Province." In Conflict and Resource Development in the Southern Highlands of Papua New Guinea, edited by Nicole Haley, 149-64. Canberra: ANU E Press.

Loeweke, Eunice, and Jean May. 1980. "General Grammar of Fasu (Namo Me)." Workpapers in Papua New Guinea Languages 27: 5-106.

Lomas, Gabe C. J. 1988. “The Huli Language of Papua New Guinea.” PhD dissertation, Macquarie University. http://hdl.handle.net/1959.14/22313.

Love, J. W. 1998. "Views from the Continent." In Australia and the Pacific Islands, edited by Adrienne L. Kaeppler and J. W. Love, 34-42. The Garland Encyclopedia of World Music, 9. New York: Garland Publishing.

Love, J. W., and Adrienne L. Kaeppler. 1998. "The Analysis of Speech in Musical Contexts." In Australia and the Pacific Islands, edited by Adrienne L. Kaeppler and J. W. Love, 321-22. The Garland Encyclopedia of World Music, 9. New York: Garland Publishing.

May, Jean, and Eunice Loeweke. 1981. Fasu (Námo Mē)-English dictionary. Ukarumpa: Summer Institute of Linguistics.

Mel, Michael A. 2005. "The Need for Strong and Balanced Communities through Education: Kang Rom (Story-telling) as a Way of Building Communities in PNG." 11 pp. Paper presented at the 2005 National Curriculum Reform Conference, 13-15 July 2005.

Merlan, Francesca. 1995. "Indigenous Narrative Genres in the Western Highlands of Papua New Guinea." In Proceedings of the Second Annual Symposium about Language and Society, Austin, edited by Pamela Silberman and Jonathan Loftin, 87-98. Texas Linguistic Forum, 34. Austin: University of Texas. 
Merlan, Francesca, and Alan Rumsey. 1991. Ku Waru: Language and Segmentary Politics in the Western Nebilyer Valley, Papua New Guinea. Studies in the Social and Cultural Foundations of Language, 10. Cambridge: Cambridge University Press.

Modjeska, Charles J. Nicholas. 1977. "Production among the Duna: Aspects of Horticultural Intensification in Central New Guinea." PhD dissertation, Australian National University.

Niles, Don. 2007. "Sonic Structure in Tom Yaya Kange: Ku Waru Sung narratives from Papua New Guinea." In Oceanic Music Encounters-the Print Resource and the Human Resource: Essays in Honour of Mervyn McLean, edited by Richard Moyle, 109-22. Research in Anthropology and Linguistics Monograph, 7. Auckland: University of Auckland.

. 2009. "Encapsulations of Indigenous Knowledge: Chanted Tales from the Papua New Guinea Highlands." In Reframing Indigenous Knowledge: Cultural Knowledge and Practices in Papua New Guinea, edited by Steven Edmund Winduo, 122-29. Waigani: Melanesian and Pacific Studies.

Niles, Don, and Michael Webb. 1987. Papua New Guinea Music Collection. Eleven cassettes and book. Boroko: Institute of Papua New Guinea Studies. IPNGS 008.

Paia, Robert, and Andrew Strathern. 1977. Beneath the Andaiya Tree: Wiru Songs. Boroko: Institute of Papua New Guinea Studies.

Pawley, Andrew. 2005. "The Chequered Career of the Trans New Guinea Hypothesis: Recent Research and Its Implications." In Papuan Pasts: Cultural, Linguistic and Biological Histories of Papuan-Speaking Peoples, ed. Andrew Pawley, Robert Attenborough, Jack Golson, and Robin Hide, 67-107. Pacific Linguistics, 572. Canberra: Australian National University.

Pugh, Jacqueline. 1975. "Communication, Language and Huli Music: A Preliminary Survey.” Honours thesis, BA with Honours, Monash University, Melbourne.

Pugh-Kitingan, Jacqueline. 1981. "An Ethnomusicological Study of the Huli of the Southern Highlands, Papua New Guinea." PhD dissertation, University of Queensland.

. 1984. "Speech-tone Realisation in Huli Music." In Problems and Solutions: Occasional Essays in Musicology Presented to Alice M. Moyle, edited by Jamie Kassler and Jill Stubington, 94-120. Sydney: Hale and Iremonger. 
. 1998. "Highland Region of Papua New Guinea: Southern Highlands Province: Huli." In Australia and the Pacific Islands, edited by Adrienne L. Kaeppler and J. W. Love, 536-43. The Garland World Encyclopedia of Music, 9. Washington: Garland Publishing.

Reichl, Karl. 2000. "Introduction: The Music and Performance of Oral Epics." In The Oral Epic: Performance and Music, edited by Karl Reichl, 1-40. Wilhelmshaven: Verlag für Wissenschaft und Bildung. Intercultural Music Studies, 12.

Reithofer, Hans. 2005. [Recordings and documentation of Karinj music and stories]. 2 compact discs. Music Archive, Institute of Papua New Guinea Studies. IPNGS x05-005.

. 2006. The Python Spirit and the Cross: Becoming Christian in a Highland Community of Papua New Guinea. Göttinger Studien zur Ethnologie, 16. Münster: LIT Verlag.

Ross, Malcolm. 2005. "Pronouns as a Preliminary Diagnostic for Grouping Papuan Languages." In Papuan Pasts: Cultural, Linguistic and Biological Histories of Papuan-Speaking Peoples, ed. Andrew Pawley, Robert Attenborough, Jack Golson, and Robin Hide, 15-65. Pacific Linguistics, 572. Canberra: Australian National University.

Rumsey, Alan. 1995. "Pairing and Parallelism in the New Guinea Highlands." In SALSA II: Proceedings of the Second Annual Symposium about Language and Society, Austin, edited by Pamela Silberman and Jonathan Loftin, 10818. Texas Linguistic Forum, 34. Austin: University of Texas.

. 2001. "Tom Yaya Kange: A Metrical Narrative Genre from the New Guinea Highlands." Journal of Linguistic Anthropology 11 (2): 193-239.

-. 2002. "Aspects of Ku Waru Ethnosyntax and Social Life." In Ethnosyntax: Explorations in Grammar and Culture, edited by Nicolas J. Enfield, 259-86. Oxford: Oxford University Press.

. 2005. "Chanted Tales in the New Guinea Highlands of Today: A Comparative Study." In Expressive Genres and Historical Change: Indonesia, Papua New Guinea, and Taiwan, edited by Pamela J. Stewart and Andrew Strathern, 41-81. Anthropology and Cultural History in Asia and the IndoPacific. Hants: Ashgate Publishing.

. 2006a. "The Articulation of Indigenous and Exogenous Orders in Highland New Guinea and Beyond." The Australian Journal of Anthropology 17 (1): 47-69. 
. 2006b. "Verbal Art, Politics, and Personal Style in Highland New Guinea and Beyond." In Language, Culture and the Individual: A Tribute to Paul Friedrich, edited by Catherine O’Neil, Mary Scoggin, and Kevin Tuite, 319-46. Munich: Lincom.

- 2007. "Musical, Poetic and Linguistic Form in Tom Yaya Sung Narratives from Papua New Guinea.” Anthropological Linguistics 49: 237-82.

2010. "A Metrical System that Defies Description by Ordinary Means." In A Journey through Austronesian and Papuan Linguistic and Cultural Space: Papers in Honour of Andrew K. Pawley, edited by John Bowden and Nikolaus Himmelmann, 39-56. Pacific Linguistics, 615. Canberra: Pacific Linguistics.

Sollis, Michael. 2006. "Tonal Variation amongst Chanted Tales of Papua New Guinea." Undergraduate research paper, Department of Anthropology and Archaeology, and Research School of Pacific and Asian Studies, Australian National University. 53 pp.

2010. "Tune-tone Relationships in Sung Duna Pikono." Australian Journal of Linguistics 30: 67-80.

Spearritt, Gordon, and Jürg Wassmann. 1996. "Myth and Music in a Middle Sepik village." Kulele: Occasional Papers on Pacific Music and Dance 2: 59-84.

Stewart, Pamela J., and Andrew Strathern. 1999. "Female Spirit Cults as a Window on Gender Relations in the Highlands of Papua New Guinea." Journal of the Royal Anthropological Institute 5: 345-60.

_. 2000a. "Naming Places: Duna Evocations of Landscape in Papua New Guinea." People and Culture in Oceania 16: 87-107.

-2000b. Speaking for Life and Death: Warfare and Compensation among the Duna of Papua New Guinea. Senri Ethnological Reports, 13. Osaka: National Museum of Ethnology.

- 2002a. Gender, Song and Sensibility: Folksongs and Folktales in the Highlands of New Guinea. Westport, CT: Praeger.

- 2002b. Remaking the World: Myth, Mining and Ritual Change among the Duna of Papua New Guinea. Smithsonian Series in Ethnographic Inquiry. Washington, DC: Smithsonian Institution Press.

_. 2005. "Duna Pikono: A Popular Contemporary Genre in the Papua New Guinea Highlands." In Expressive Genres and Historical Change: Indonesia, 
Papua New Guinea and Taiwan, edited by Pamela J. Stewart and Andrew Strathern, 83-107. Anthropology and Cultural History in Asia and the IndoPacific Series. Hants: Ashgate.

Strathern, Andrew. 1971. The Rope of Moka: Big-men and Ceremonial Exchange in Mount Hagen, New Guinea. Cambridge Studies in Social Anthropology, 4. Cambridge: Cambridge University Press. (re-issued with corrections and new preface, 2007.)

—. 1983. "The Melpa." Radio programme script prepared for the National Broadcasting Commission. 4 pp.

. 1995. "Chant and Spell: Sonemic Contrasts in a Melpa Ritual Sequence." Ethnomusicology 39 (2) (Spring/Summer): 219-27.

. 1998. "Highland Region of Papua New Guinea: Western Highlands Province: Melpa." In Australia and the Pacific Islands, edited by Adrienne L. Kaeppler and J. W. Love, 516-22. The Garland Encyclopedia of World Music, 9. New York: Garland Publishing.

Strathern Andrew, and Pamela J. Stewart. 1997. Ballads as Popular Performance Art in Papua New Guinea and Scotland. Centre for Pacific Studies Discussion Papers Series, 2. Townsville: James Cook University of North Queensland.

. 2000. "Melpa Ballads as Popular Performance Art." In Papers from Ivilikou: Papua New Guinea Music Conference and Festival (1997), edited by Don Niles and Denis Crowdy, 76-84. With one cassette. Boroko: Institute of Papua New Guinea Studies and University of Papua New Guinea.

. 2004. Empowering the Past, Confronting the Future: The Duna People of Papua New Guinea. Contemporary Anthropology of Religion Series. New York: Palgrave Macmillan.

. 2005a. "Introduction." In Expressive Genres and Historical Change: Indonesia, Papua New Guinea and Taiwan, edited by Pamela J. Stewart and Andrew Strathern, 1-39. Anthropology and Cultural History in Asia and the Indo-Pacific. Hants: Ashgate Publishing.

. 2005b. "Melpa Songs and Ballads: Junctures of Sympathy and Desire in Mount Hagen, Papua New Guinea." In Expressive Genres and Historical Change: Indonesia, Papua New Guinea and Taiwan, edited by Pamela J. Stewart and Andrew Strathern, 201-33. Anthropology and Cultural History in Asia and the Indo-Pacific. Hants: Ashgate Publishing.

Talyaga, Kundapen. 1973. Enga Eda Nemago: Meri Singsing Poetry of the Yandapo Engas. Papua Pocket Poets, 40. Port Moresby: [n.p.]. 
Voorhoeve, C. L. 1975. "Central and Western Trans-New Guinea Phylum Languages." In New Guinea Area Languages and Language Study, Vol. 1:Papuan Languages and the New Guinea Linguistic Scene, edited by Stephen A. Wurm, 345-459. Pacific Linguistics, C 38. Canberra: Australian National University.

. 1977. "Ta-poman: Metaphorical Use of Words and Poetic Vocabulary in Asmat Songs." In New Guinea Area Languages and Language Study, Vol. 3: Language, Culture, Society and the Modern World, edited by Stephen A. Wurm, 19-38. Pacific Linguistics, C 40. Canberra: Australian National University.

Wassmann, Jürg. 1991. The Song to the Flying Fox: The Public and Esoteric Knowledge of the Important Men of Kandingei about Totemic Songs, Names and Knotted Cords (Middle Sepik, Papua New Guinea). Translated by Dennis Q. Stephenson. Apwitihire: Studies in Papua New Guinea Musics, 2. Boroko: National Research Institute.

Wiessner, Polly, and Akii Tumu. 1998. Historical Vines: Enga Networks of Exchange, Ritual, and Warfare in Papua New Guinea. Smithsonian Series in Ethnographic Inquiry. Bathurst: Crawford House Publishing. 